\title{
CoNF-97083t--11
}

\section{ANALYSIS OF NANOMETER-SCALE PRECIPITATION IN A RAPIDLY SOLIDIFIED STAINLESS STEEL}

\author{
S. Wisutmethangoon", T.F. Kelly", P.P. Camus", J.E. Flinn ${ }^{* *}$, D.J. Larson ${ }^{* * *}$, and M.K. Miller ${ }^{* * *}$ \\ "Department of Materials Science and Engineering, University of Wisconsin, Madison, WI 53706, \\ "formerly of Idaho National Engineering Laboratory, Idaho Falis, ID 83415, "Metals and \\ Ceramics Division, Oak Ridge National Laboratory, Oak Ridge, TN 37831
}

Though stainless stcels are important technologically for a wide range of applications, they are not generally known for their very high strength. We have rapid-solidification-processed many stainless steels by gas atomization and achieved strength improvements of over $50 \%$ relative to conventionally-processed stainiess steels with concomitant improvement in corrosion and oxidation behavior.' These strength improvements are most pronounced after aging treatments when elevated concentrations of oxygen and vanadium are present in the stainless steel. An austenitic (FCC) stainiess steel (Fe-16\% Ni-9\% Cr-0.5\%Mn- $0.2 \% \mathrm{~V}-0.0137 \% \mathrm{~N}-0.008 \% \mathrm{O}$ by weight) was prepared by gas atomization and consolidated by hot extrusion at $900^{\circ} \mathrm{C}$. These specimens were heat treated for 1 hour at $1000^{\circ} \mathrm{C}$ and aged at $600^{\circ} \mathrm{C}$ for 500 hours.

The microstructure of each alloy composition was observed in TEM with bright field imaging. After aging, most alloys showed the same precipitate morphology as before aging. An obvious change, however, was found only in the alloy with highest oxygen content. A high number density $(2.2 \times$ $10^{20} \mathrm{~m}^{-3}$ ) of 15 to $20 \mathrm{~nm}$ (18 nm average) diameter precipitates was measured in this alloy. Moreover, with weak-beam dark field imaging, a very high number density $\left(\sim 2 \times 10^{22} \mathrm{~m}^{\cdot 3}\right)$ of coherent, 6 to $10 \mathrm{~nm}$ ( $8 \mathrm{~nm}$ average) diametcr precipitates is observed throughout the matrix by Moire fringe contrast, Fig. la. This image was Fourier filtered to select only the Moire fringe spatial frequency and the result is shown in Fig. 1b. From the fringe spacing and diffraction pattern, the 8 $\mathrm{nm}$ precipitates are FCC with a lattice parameter of $0.40 \mathrm{~nm}$.

These fringes appear only in the aged specimen. An atom probe field ion microscopy (APFIM) investigation showed that FIM provides high contrast imaging the precipitates. ${ }^{2}$ The $18 \mathrm{~nm}$ precipitates are complex oxides of $\mathrm{Fe}, \mathrm{Cr}$, and $\mathrm{Ni}$ with an average composition of $44 \% \mathrm{O}, 31 \% \mathrm{Fe}$, $13 \% \mathrm{Cr}, 10 \% \mathrm{Ni}, 3 \% \mathrm{Ar}$, Fig. 2 . Only one of three oxide precipitates was found to contain argon. Argon was used as the cooling gas in the powder processing. The $18 \mathrm{~nm}$ oxide precipitates appear dark with respect to the matrix in the FIM image. The $8 \mathrm{~nm}$ precipitates appear bright compared to the matrix and were found to be complex nitrides of $\mathrm{Fe}, \mathrm{Cr}, \mathrm{V}$, and $\mathrm{C}$ with the average composition of $41.5 \% \mathrm{~V}, 27.6 \% \mathrm{~N}, 18 \% \mathrm{Cr}, 8.6 \% \mathrm{Fe}, 2.4 \% \mathrm{C}, 1 \% \mathrm{Ni}, 0.37 \% \mathrm{Al}, 0.26 \% \mathrm{Mn}$.

In order to get a more global view of the structure, energy-filtered composition imaging on a LEO EM 912 was used to map the oxygen and nitrogen in carbon extraction replicas of the aged specimens, Fig. 4. These images confirm that the $18 \mathrm{~nm}$ precipitates are oxides, however, it appears that the 8 um precipitates are not extracted.

\section{References}

1 J. E. Flinn and T. F. Kelly, US patent application submitted April 1996.

2 T. F. Kelly, S. Wisumethangoon, D. J. Larson, and M. K. Miller, these proccedings.

3 This research was sponsored by the Division of Materials Sciences, U. S. Department of Energy, under contract DE-AC05-960R22464 with Lockheed Martin Energy Research Corp., by the U. S. Department of Energy and was conducted utilizing the Shared Research Equipment User Program facilities at Oak Ridge National Laboratory.

\section{DISTRIBUTION OF THIS DOCUMENT IS UNLIMITED}

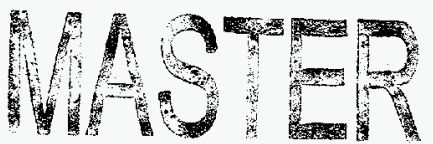

The submitted manuscripe has been authored by a contractor

of the U.S. Govermment under contract No. DE-ACUS-960R

Accordingly, the U.S. Govermment retains a nonexclusive.

myaity-tree license to publish or repmduce the published form
of this contribution. ur allow others to do so. for U.S. Governmem purposes." 


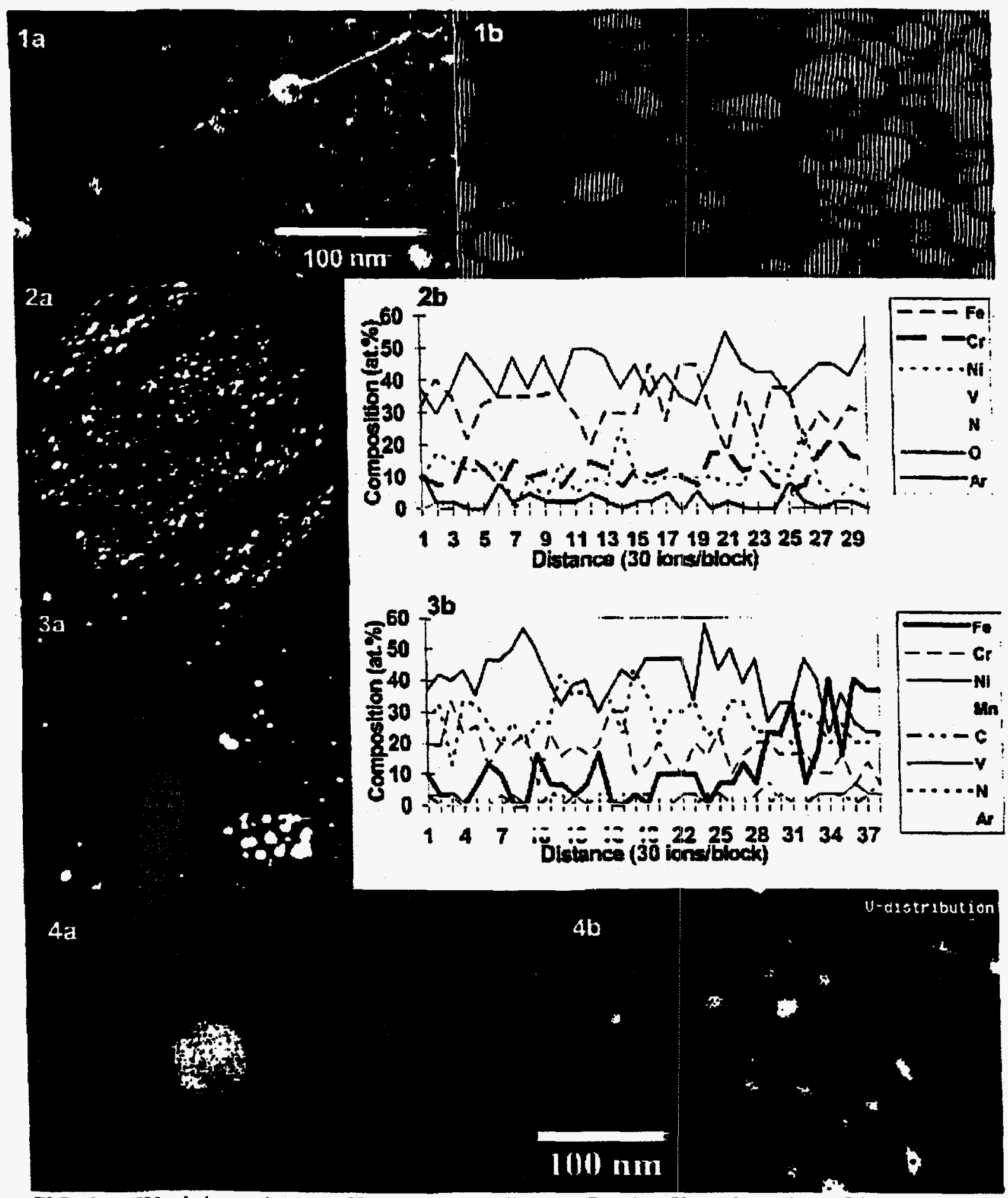

FIG. 1 a) Weak-beam image of Fe-16Ni-9Cr alloy. b) Fourier-filtered version of 1 a.

FIG. 2 a) FIM image of a $18 \mathrm{~nm}$ oxide precipitate. b) Atom probe profile through the precipitatc. FIG. 3 a) FIM imagc of a 8 nu nitride precipitate. b) Atom probe profile through the precipitate. FIG. 4 a) Energy-filtered oxygen image of an extraction replica. b) Vanadium image. 


\section{DISCLAIMER}

This report was prepared as an account of work sponsored by an agency of the United States Government. Neither the United States Government nor any agency thereof, nor any of their employees, makes any warranty, express or implied, or assumes any legal liability or responsibility for the accuracy, completeness, or usefulness of any information, apparatus, product, or process disclosed, or represents that its use would not infringe privately owned rights. Reference herein to any specific commercial product, process, or service by trade name, trademark, manufacturer, or otherwise does not necessarily constitute or imply its endorsement, recommendation, or favoring by the United States Government or any agency thereof. The views and opinions of authors expressed herein do not necessarily state or reflect those of the United States Government or any agency thereof. 


\section{DISCLAMMER}

Portions of this document may be illegible in electronic image products. Images are produced from the best available original document. 